\title{
Reflections on US Policies regarding Effective Regulation and Discipline and Foreign Lawyer Mobility: Has the Time Come to Talk about the Elephant in the Room
}

\author{
Laurel S. Terry
}

Iterry@psu.edu

Follow this and additional works at: https://ideas.dickinsonlaw.psu.edu/fac-works

Part of the International Trade Law Commons, Legal Ethics and Professional Responsibility Commons, and the Legal Profession Commons

\section{Recommended Citation}

Laurel S. Terry, Reflections on US Policies regarding Effective Regulation and Discipline and Foreign Lawyer Mobility: Has the Time Come to Talk about the Elephant in the Room, 16 Legal Ethics 284 (2013).

This Article is brought to you for free and open access by the Faculty Scholarship at Dickinson Law IDEAS. It has been accepted for inclusion in Faculty Scholarly Works by an authorized administrator of Dickinson Law IDEAS. For more information, please contact lja10@psu.edu. 


\title{
Reflections on US Policies Regarding 'Effective Regulation and Discipline' and Foreign Lawyer Mobility: Has the Time Come to Talk About the Elephant in the Room?
}

\author{
Laurel S Terry
}

\section{INTRODUCTION}

The thesis of this article is that there is an elephant in the room that no one has been willing to discuss, but the time has come to bring this issue out into the open and begin a dialogue. The 'elephant' is the fact that the ABA's 'foreign lawyer' mobility recommendations and a number of US state rules require a foreign lawyer who practises in the US to be 'subject to effective regulation and discipline' in the lawyer's home [foreign] jurisdiction but there has never been a serious discussion about what this requirement means or how it should be enforced. ${ }^{1}$ Nor is it clear whether or how those US states that have adopted this aspect of the ABA foreign lawyer model rules have implemented this black letter language. Furthermore, to my knowledge, the 'effective regulation and discipline' requirement in the foreign lawyer mobility model rules has not been the subject of discussion or debate by commentators. ${ }^{2}$ Those commentators who have encouraged adoption of the ABA foreign lawyer mobility policies have done so without knowing what this element means. ${ }^{3}$ The time has come to talk about the elephant in the room, even if it is an uncomfortable conversation for those who favour greater lawyer mobility.

* Professor of Law, Penn State Dickinson School of Law, USA. Email: LTerry@psu.edu. All urls were accurate as of 31 October 2013. The author would like to thank Carole Silver, Reid Mortensen and Rachel Scheck for their assistance with this article. Her articles are available on ssrn.com.

1 The term 'foreign lawyers' is used in this article to refer to those who are regulated lawyers in their 'home jurisdiction' but are not fully admitted to practice in any US jurisdiction. Thus, the US is a 'host jurisdiction' for these 'foreign' [to the US] lawyers. This terminology of host jurisdiction, home jurisdiction and foreign lawyer is frequently used. See eg International Bar Association, Resolution on Transfer of Skills and Liberalization of Trade in Legal Services (Adopted Buenos Aires 2008), www.americanbar.org/content $/ \mathrm{dam} / \mathrm{aba} / \mathrm{migrated} / \mathrm{cpr} /$ gats/iba.authcheckdam.pdf (incorporating by reference the 1998 definitions); International Bar Association (IBA), Statement of General Principles for the Establishment and Regulation of Foreign Lawyers (Adopted Vienna, 1998) (defining these terms), www.americanbarorg/content/dam/aba/migrated/cpr/gats/iba_establish ment.authcheckdam.pdf.

2 One of the few exceptions of which I am aware is a paper written by one of my seminar students, which is posted on SSRN. See Rachel Schreck, 'Lawyer Discipline: What is Considered "Effective Discipline?"', http:// papers.ssrn.com/sol3/papers.cfm?abstract_id=1631256.

3 I include myself in this group. 


\section{BACKGROUND INFORMATION}

\section{A. Overview}

As a result of globalisation, it is routine for corporate clients to buy and sell products and services in other countries. ${ }^{4}$ Global lawyer mobility has increased in an effort to serve those clients. ${ }^{5}$ Global lawyer mobility has also increased in response to the needs of individual clients. The US and other countries such as Canada and the UK have large numbers of foreign-born inhabitants. ${ }^{6}$ In an era in which travel and technology are easy, it should not be surprising that individual clients also have legal needs outside their home country. ${ }^{7}$ For all of these reasons, the ABA and a number of commentators have urged US states and other jurisdictions to create conditions under which foreign lawyers might work in the US in order to assist clients with cross-border legal needs. ${ }^{8}$

There are five methods by which foreign lawyers might practise in the US:

- practise under a limited law licence that allows the foreign lawyer to practise Home Country [foreign] law, and perhaps other kinds of law such as international law, third party law, or domestic [Host Country] law if properly supervised;

- temporary practice, also known as fly-in-fly-out or FIFO;

- practising as in-house counsel;

- pro hac vice ('for this time only') admission to appear before a court in a pending lawsuit; and

- full admission as a lawyer licensed by a US state. Full admission may come about through an admission on motion process or by way of a bar examination, but either method will probably include additional requirements such as a character and fitness inquiry. ${ }^{9}$

4 See generally Laurel S Terry, 'The Legal World is Flat: Globalization and its Effect on Lawyers Practicing in Non-Global Law Firms' (2008) 28 Northwestern Journal of International Law \& Business 527; US Bureau of Economic Affairs, International Economic Accounts, www.bea.gov/international/index.htm\#bop (includes numerous links to various kinds of international trade data, showing extensive trade by clients).

5 See eg Council for Trade in Services, Legal Services-Background Note by the Secretariat, S/C/W/318 (14 June 2010), para 12 [hereinafter 2010 WTO Report]; Recent Trends in US Services Trade: 2011 Annual Report, Inv No 332-345, USITC Pub 4243 (July 2011) (Final) at 7-1, www.usitc.gov/publications/332/pub4243.pdf.

6 See eg Terry (n 4) 528-9; ABA Commission on Ethics 20/20, Inbound Foreign Lawyer Memoranda \& Template (released 1 June 2010), 4,www.americanbar.org/content/dam/aba/migrated/2011_build/ethics_2020/inbound_ foreign_lawyer memo templates.authcheckdam.pdf; Laurel S Terry, 'Trends in Global and Canadian Lawyer Regulation' (2013) 76 Saskatchewan Law Review 145, 149-51 (discussing a StatsCanada report on projected diversity in 2031).

7 See Terry ( $n$ 4). To illustrate this point, several years ago, out of curiosity, I joined the listserv of the International Family Law Committee of the American Bar Association (ABA) Section of International Law. I am regularly impressed by the volume of email traffic and the cross-border situations in which individual US clients find themselves.

8 See eg below, nn 11-14 for a discussion of ABA policies; Carole Silver, 'Regulatory Mismatch in the International Market for Legal Services' (2003) 23 Northwestern Journal of International Law \& Business 487.

9 See eg ABA Task Force on International Trade in Legal Services, International Trade in Legal Services and Professional Regulation: A Framework for State Bars Based on the Georgia Experience (4 February 2012) (uses this five-part structure). This Toolkit is available at http://arbitrateatlanta.org/wp-content/uploads/2011/08/ FINAL-ITILS-toolkit-2-4-12.pdf. There is an updated January 2014 version that appears at http://tinyurl.com/ GAtoolkit. 
For the first four methods listed above, the ABA has adopted model policies that it recommends to US states for adoption. ${ }^{10}$ These four ABA policies are:

- the ABA Model Rule for the Licensing and Practice of Foreign Legal Consultants (adopted in 1993, reaffirmed in 2002; revised in 2006) ${ }^{11}$

- the ABA Model Rule for Temporary Practice by Foreign Lawyers, which was adopted in $2002 ;^{12}$

- the 2013 addition of foreign in-house counsel to ABA Model Rule 5.5 and to the ABA Model Rule for Registration of In-House Counsel; ${ }^{13}$ and

- the 2013 addition of foreign lawyers to the ABA Model Rule on Pro Hac Vice Admission. ${ }^{14}$

10 As most readers probably know, regulation of US lawyers is primarily handled by the judicial branch of each state. See eg ABA Commission on Multijurisdictional Practice, Report 201A (Regulation of the Practice of Law by the Judiciary) (adopted 12 August 2002), www.americanbar.org/content/dam/aba/migrated/cpr/mjp/201a. authcheckdam.pdf; National Organization of Bar Counsel, www.nobc.org (select top drop-down menu for 'Research', which links to state rules of admission, disciplinary rules, professional conduct rules and resources, among other things). A state-by-state comparison of individual ABA Model Rules of Professional Conduct can be found on the webpage of the ABA Center for Professional Responsibility, www.americanbar.org/groups/ professional_responsibility/policy/rule_charts.html.

11 See ABA Model Rule for the Licensing and Practice of Foreign Legal Consultants (2006), www.americanbar. org/content/dam/aba/migrated/cpr/mjp/FLC.authcheckdam.pdf [hereinafter 2006 ABA Model FLC Rule]. The prior versions are ABA Commission on Multijurisdictional Practice, Report to the House of Delegates and Recommendation Report $201 \mathrm{H}$ (adopted 12 August 2002) [hereinafter 2002 ABA Model FLC Rule], www.americanbar.org/content/dam/aba/migrated/cpr/mip/201h.authcheckdam.pdf ('RESOLVED, that the American Bar Association encourage jurisdictions to adopt the ABA Model Rule for the Licensing of Legal Consultants, dated August 1993'). The 1993 Model FLC rule is attached to the 2002 report.

12 ABA Commission on Multijurisdictional Practice, Report to the House of Delegates and Recommendation, Report $201 \mathrm{~J}$ (adopted 12 August 2002), www.americanbar.org/content/dam/aba/migrated $/ \mathrm{cpr} / \mathrm{mjp} / 201 j$. authcheckdam.pdf [hereinafter ABA MJP Report 201J].

13 See ABA Commission on Ethics 20/20 et al, Report to the House of Delegates and Resolution Revised 107A (adopted 11 February 2013), www.americanbar.org/content/dam/aba/administrative/ethics_2020/20130201_revised resolution_107a_resolution_only_redline.authcheckdam.pdf [hereinafter Revised Report 107A re Foreign In-House Counsel]; ABA Commission on Ethics 20/20 et al, Report to the House of Delegates and Resolution, [Revised] Model Rule for Registration of In-House Counsel (adopted 11 February 2013), www.americanbar.org/ content/dam/aba/administrative/ethics_2020/20130201_revised_resolution_107b_resolution_only_redline. authcheckdam.pdf [hereinafter Revised Report 107B re In-house Counsel Registration]. The report that explains the reasoning underlying the Commission's proposal is found in the initial filing (see Original Report $107 \mathrm{~A}$ ( $\mathrm{n} 31$ ) below), but not the revised version of Report 107A cited above.

14 See ABA Commission On Ethics 20/20 et al, Report to the House of Delegates and Resolution Amended 107C (adopted 11 February 2013), www.americanbarorg/content/dam/aba/administrative/ethics_2020/2013_hod midyear_meeting_107c_redline_with_floor_amendment.authcheckdam.pdf [hereinafter Amended Report $107 \mathrm{C}$ re Pro Hac Vice]. The report that explains the reasoning underlying the Commission's proposal is found in the initial filing, but not the amended version of Report $107 \mathrm{C}$ cited above. See ABA Commission on Ethics 20/20 et al, Report to the House of Delegates and Resolution, ABA Model Rule on Pro Hac Vice, www.americanbar. $\mathrm{org} /$ content/dam/aba/administrative/ethics_2020/20121211_ethics_20_20_Pro_hac_vice_foreign_lawyers_ resolution_report_final.authcheckdam.pdf [hereinafter Original 107C Report]. 
The ABA has discussed, but not yet adopted, a model policy relevant to full admission of foreign lawyers, which is the fifth way in which a foreign lawyer might practise in the US. ${ }^{15}$

These ABA model policies regarding foreign lawyer mobility have had a mixed record with respect to state implementation. Thirty-two US jurisdictions have a foreign legal consultant (FLC) rule that grants foreign lawyers the right to practise in that jurisdiction pursuant to a limited [FLC] license. ${ }^{16}$ Although this is less than two-thirds of US jurisdictions, in 2008, the ABA calculated that the jurisdictions that have FLC rules are home to approximately 80 per cent of actively licensed US lawyers. ${ }^{17}$

In contrast to the FLC rule, the ABA's temporary practice rule for foreign lawyers, which is often referred to as the FIFO rule, has been adopted in only a handful of US states. ${ }^{18}$ This

15 In 2011, the Council of the ABA Section of Legal Education and Admissions to the Bar circulated for public comment a proposed Model Rule on Admission of Foreign Educated Lawyers and proposed Criteria for ABA Certification of an LLM Degree for the Practice of Law in the United States that had been prepared by its International Committee. This Model Rule and accompanying Criteria recommended that foreign lawyers be permitted to sit for a state bar examination provided that they had received an LLM degree from a school that had been certified as offering an LLM degree for the practice of the law in the United States. See ABA Section of Legal Education and Admissions to the Bar, Proposed Model Rule on Admission of Foreign Educated Lawyers and Proposed Criteria for ABA Certification of an LLM Degree for the Practice of Law in the United States (7 October 2011), www.americanbar.org/content/dam/aba/administrative/legal_education_and_admissions_ to_the_bar/council_reports_and_resolutions/20110420_model_rule_and_criteria_foreign_lawyers. authcheckdam.pdf. After receiving a number of comments, the Council took no further action and the $\mathrm{ABA}$ remains without a model policy on the full admission issue. See ABA Section of Legal Education and Admission to the Bar, Comments Received as of 27 September 2011, www.americanbar.org/content/dam/ aba/administrative/legal_education_and_admissions_to_the_bar/20110927_comments_proposed_rule_ criteria_foreign_educated_lawyers.authcheckdam.pdf; Laurel S Terry, 'Transnational Legal Practice (United States) [2010-12]' (2013) 47 International Lawyer 499, 506; Carole Silver, 'Globalization and the Monopoly of ABA-Approved Law Schools: Missed Opportunities or Dodged Bullets?’ (2014) 82 Fordham Law Review (forthcoming).

16 The 32 jurisdictions that have FLC rules are: 1) Alaska, 2) Arizona, 3) California, 4) Connecticut, 5) Delaware, 6) the District of Columbia, 7) Florida, 8) Georgia, 9) Hawaii, 10) Idaho, 11) Illinois, 12) Indiana, 13) Iowa, 14) Louisiana, 15) Massachusetts, 16) Michigan, 17) Minnesota, 18) Missouri, 19) New Hampshire, 20) New Jersey, 21) New Mexico, 22) New York, 23) North Carolina, 24) North Dakota, 25) Ohio, 26) Oregon, 27) Pennsylvania, 28) South Carolina, 29) Texas, 30) Utah, 31) Virginia and 32) Washington. See generally ABA Center for Professional Responsibility, Commission on Multijurisdictional Practice, www.americanbar.org/ groups/professional_responsibility/committees_commissions/commission_on_multijurisditional_practice. html (right-hand side of the page links to all FLC rules); National Conference of Bar Examiners, Comprehensive Guide to Bar Admissions 2014, Chart 13: Other Licenses and Registrations/Fees, www.ncbex.org/assets/media files/Comp-Guide/CompGuide.pdf (lists all rules). Some of these FLC rules, however, differ from the ABA Model FLC Rule in significant ways. See Carole Silver and Nicole DeBruin, Comparative Analysis of United States Rules Licensing Legal Consultants (May 2006), www.americanbar.org/content/dam/aba/migrated/cpr/ mjp/silver_flc_chart.authcheckdam.pdf.

17 See eg Laurel S Terry, Quick Guide Chart on State Adoption of MJP Recommendations 8 and 9, www.americanbar. org/content/dam/aba/migrated/cpr/mjp/8_and_9_status_chart.authcheckdam.pdf; Laurel S Terry, Carole Silver, Ellyn Rosen, Carol Needham, Robert E Lutz and Peter D Ehrenhaft, 'Transnational Legal Practice: 2006-07 Year-in-Review' (2008) 42 International Lawyer 833, 844 fn 62.

18 See Quick Guide, ibid; ABA Center for Professional Responsibility Policy Implementation Committee, State Rules: Temporary Practice by Foreign Lawyers (30 October 2013), www.americanbar.org/content/dam/aba/ administrative/professional_responsibility/temporary_practice_foreign_lawyers_fifo.authcheckdam.pdf. These states are: 1) Delaware, 2) Florida, 3) Georgia, 4) New Hampshire, 5) North Carolina, 6) Pennsylvania and 7) Virginia. Some states, including Florida, Georgia and New Hampshire, have incorporated the effective regulation and discipline' requirement. 
lack of success may be due to the fact that, despite discussion, the ABA temporary practice rule was not incorporated into Rule 5.5 of the Model Rules of Professional Conduct and thus it is an 'orphan' policy that does not clearly fall within the jurisdiction of any state bar committee or entity. The 2013 foreign lawyer mobility provisions that address in-house counsel and pro hac vice are too new to have generated state implementation, although a number of US states had similar policies that predated the ABA policy. ${ }^{19}$

\section{B. Lawyer Regulation and Discipline Provisions in US Foreign Lawyer Model Policies}

All of the ABA's model policies on foreign lawyer mobility include a requirement that addresses the regulatory system in the foreign lawyer's home jurisdiction. This requirement was first included in the original 1993 ABA Model Foreign Legal Consultant rule and has been repeated in all of the ABA's subsequent policies regarding foreign lawyer mobility. For example, the current version of the ABA Model FLC Rule states in pertinent part:

[to qualify, the FLC] is, and for at least five years has been, a member in good standing of a recognized legal profession in a foreign country, the members of which are admitted to practice as lawyers or counselors at law or the equivalent and are subject to effective regulation and discipline by a duly constituted professional body or a public authority. ${ }^{20}$

The report that accompanied the 1993 ABA Model FLC rule contained the following explanation of the 'effective regulation and discipline' requirement:

Subsection 1(a) requires that an applicant for a license to practice as a legal consultant be a member in good standing of a recognized legal profession in a foreign country, the members of which are admitted to practice as attorneys or counselors at law or the equivalent and are subject to effective regulation and discipline by a duly constituted professional body or a public authority. This is a somewhat more elaborate requirement than that utilized in the New York Rule and most other existing Rules, which generally require that the applicant have been 'admitted to practice and [be] in good standing as an attorney or counselor at law or the equivalent in a foreign country. ${ }^{\text {[f } 32]}$ The reason for the Model Rule's elaboration upon this usage is to make it clear that there are certain aspects of the applicant's legal profession that are essential prerequisites to his or her licensing as a legal consultant, namely, that it be recognized as a legal profession and that it be subject to effective professional regulation and discipline. ${ }^{[\mathrm{fn} 33]}$ The licensing of foreign lawyers

19 See ibid, 2 (showing adoption of foreign in-house counsel rules by Arizona, Connecticut, Delaware, Georgia, Indiana, Virginia, Washington and Wisconsin); Original 107C Report (n 14) 1 (indicating that at least 15 states, the US Supreme Court and a number of lower federal courts already allow pro hac vice admission for lawyers who are not licensed in the US). See also ABA Center for Professional Responsibility Policy Implementation Committee, Comparison of ABA Model Rule for Pro Hac Vice Admission with State Versions and Amendments since August 2002 (as of 31 July 2013), www.americanbar.org/content/dam/aba/administrative/ professional_responsibility/prohac_admin_comp.authcheckdam.pdf (showing foreign pro hac vice rules in: 1) the District of Columbia, 2) Florida, 3) Georgia, 4) Illinois, 5) Maine, 6) Michigan, 7) New Mexico, 8) New York, 9) Ohio, 10) Oklahoma, 11) Oregon, 12) Pennsylvania, 13) Utah (in the appellate courts), 14) West Virginia and 15) Wisconsin (court discretion)). See also ABA Center for Professional Responsibility Policy Implementation Committee, State by State Adoption of Selected Ethics 20-20 Commission Policies (30 October 2013), www.americanbar.org/content/dam/aba/administrative/professional_responsibility/state_implemen tation_selected_e20_20_rules.authcheckdam.pdf.

20 See 2006 ABA Model FLC Rule (n 11) \$1(a) (emphasis added). 
as legal consultants presupposes, not only that they have the necessary knowledge, but also that they are generally subject to the same kinds of ethical and legal requirements and professional discipline as members of the legal profession in the United States. ${ }^{21}$

Footnote 32 of the 1993 FLC Report cited without further explanation a number of existing FLC rules, including the New York rule. ${ }^{22}$ Footnote 33 cited the Florida FLC rule and pointed out the way in which its 'discipline system' requirement differed from both the New York rule and the proposed ABA Model Rule. ${ }^{23}$

The inclusion of the 'effective regulation and discipline' requirement in the ABA Model FLC rule suggests a careful balancing act by the rule drafters. On the one hand, it appears that the drafters wanted to include a provision that was less strict than the Florida provision since Florida's 'generally consistent' language might be interpreted to require a regulatory and disciplinary system that was substantially identical to that found in the US jurisdiction. On the other hand, the ABA Model Rule drafters may have believed that the New York approach would not satisfy everyone and that it was necessary to address the disciplinary and regulatory issue. Regardless of whether this speculation is accurate, it is clear that neither the ABA Model FLC rule itself nor the accompanying report provided any additional detail concerning the meaning of the phrase 'subjective to effective regulation and discipline by a duly constituted professional body or a public authority. ${ }^{24}$

Despite the lack of explanation in the 1993 ABA FLC rule concerning the meaning of the phrase 'subject to effective regulation and discipline by a duly constituted professional body or a public authority', this requirement has been repeated in all of the ABA's subsequent policies dealing with foreign lawyer mobility. For example, in 2002, around a decade after the ABA Model FLC Rule was adopted, the ABA Commission on Multijurisdictional Practice developed a model rule on temporary practice by foreign lawyers and included this requirement:

21 See Louis B Sohn, 'Section Recommendation and Report' (1994) 28 International Lawyer 207, 220 (emphasis added). The 1993 and 2002 versions of the ABA Model FLC Rule used slightly different language, but they were identical with respect to the 'recognized legal profession' and 'subject to effect regulation and discipline' language. Compare Sohn, 'Section Recommendation and Report' at 220 with the 2002 ABA Model FLC Rule (n 11) at 2 (" to qualify, the FLC] is a member in good standing of a recognized legal profession in a foreign country, the members of which are admitted to practice as attorneys or counselors at law or the equivalent and are subject to effective regulation and discipline by a duly constituted professional body or a public authority'). When the ABA Model FLC Rule was affirmed in 2002 and amended in 2006, there was nothing in the accompanying $\mathrm{ABA}$ reports that addressed the disciplinary system requirement.

22 Sohn (n 21) fn 32. This footnote stated, 'See New York Rule, $\$ 521.1$ (a)'. It continued by stating 'see also' and then citing without additional explanation particular subsections of the FLC rules in Alaska, California, Connecticut, the District of Colombia, Florida, Georgia, Hawaii, Illinois, Michigan, New Jersey, Ohio, Oregon, Texas and Washington.

23 Ibid, fn 33. This footnote stated in full: "While the Rules of other jurisdictions assume that the legal profession to which the applicant is admitted has a system of professional discipline comparable to those in the United States, the Florida Rule is unique in requiring that an applicant for licensing as a legal consultant be 'admitted to practice in a foreign country whose professional disciplinary system for attorneys is generally consistent with that of the Florida Bar'. Florida Rule, r 16-1.2(c).

24 See generally Sohn (n 21). 
(b) For purposes of this grant of authority, the lawyer must be a member in good standing of a recognized legal profession in a foreign jurisdiction, the members of which are admitted to practice as lawyers or counselors at law or the equivalent and subject to effective regulation and discipline by a duly constituted professional body or a public authority. ${ }^{25}$

The report accompanying the foreign lawyer temporary practice rule did not explain how a jurisdiction should determine whether the foreign lawyer's home jurisdiction had a system of 'effective regulation and discipline. ${ }^{26}$

When ABA Model Rule of Professional Conduct 5.5 was revised in 2013 to add foreign in-house counsel to its safe harbour provisions, the following language concerning regulatory and disciplinary systems was included:

(e) For purposes of paragraph (d), the foreign lawyer must be a member in good standing of a recognized legal profession in a foreign jurisdiction, the members of which are admitted to practice as lawyers or counselors at law or the equivalent, and are subject to effective regulation and discipline by a duly constituted professional body or a public authority. ${ }^{27}$

This change was part of a set of proposals from the ABA Commission on Ethics 20/20. ${ }^{28}$ The same set of proposals included the revisions to the ABA Model Rule on Pro Hac Vice Admission. ${ }^{29}$ As a result of the 2013 amendments, this rule now includes similar language requiring the foreign lawyer to come from a system that has effective regulation and discipline:

A foreign lawyer is a person admitted in a non-United States jurisdiction and who is a member of a recognized legal profession in that jurisdiction, the members of which are admitted to practice as lawyers or counselors at law or the equivalent and are subject to effective regulation and discipline by a duly constituted professional body or a public authority, and who is not disbarred, suspended or the equivalent thereof from practice in any jurisdiction. ${ }^{30}$

The reports accompanying the 2013 foreign lawyer mobility proposals mentioned the 'effective regulation and discipline' requirement, but did not explain what this requirement

25 See ABA MJP Report 201J (n 12) $\$ B$ (emphasis added).

26 See $i$ bid, at 1 . The report accompanying the $2002 \mathrm{MJP}$ proposal regarding temporary practice by foreign lawyers was similarly devoid of detail. This report simply stated: 'To come within the proposal, a lawyer must be a member in good standing of a recognized legal profession in the lawyer's home country, and the members of that profession must be subject to effective regulation and discipline by a duly constituted professional body or public authority.

27 Revised Report 107A (n 13) r 5.5(e) (emphasis added). The ABA Model Rule on in-house counsel registration was similarly expanded to include registration of foreign in-house counsel and the following definition was added to the Model Rule: 'For purposes of this Rule, a "foreign lawyer" is a member in good standing of a recognized legal profession in a foreign jurisdiction, the members of which are admitted to practice as lawyers or counselors at law or the equivalent and subject to effective regulation and discipline by a duly constituted professional body or a public authority.' Revised Report 107B (n 13) at A on p 2.

28 See generally ABA Commission on Ethics 20/20, House of Delegates Filings, www.americanbar.org/groups/ professional_responsibility/aba_commission_on_ethics_20_20/house_of_delegates_filings.html.

29 Amended Report 107C (n 14).

30 Amended Report 107C (n 14) III(A) (emphasis added). The foreign lawyer full admission proposal, cited above at $\mathrm{n} 15$, did not contain comparable language. Because this proposal was never acted upon by the Council of the ABA Section of Legal Education and Admissions to the Bar, we do not know whether this omission might have been corrected before adoption. 
meant or how it should be enforced. ${ }^{31}$

In sum, all of the existing ABA model policies on foreign lawyer mobility include a requirement that the mobile foreign lawyer is subject to effective regulation and discipline by a duly constituted professional body or a public authority in the lawyer's home jurisdiction. Neither these ABA Model Rules nor the reports that accompanied them, however, explain what is meant by this requirement or how it should be measured.

Some states, particularly those that adopted an FLC rule after the 2002 adoption of the ABA MJP Recommendation 8 regarding FLCs, have included an 'effective regulation and discipline' requirement in their FLC rule. ${ }^{32}$ Many jurisdictions, however, have not. ${ }^{33}$ Some, but not all, US states have included the 'effective regulation and discipline' provisions in their foreign lawyer temporary practice rules. ${ }^{34}$ Some but not all have included it in their rules that allow foreign in-house counsel. ${ }^{35}$ None have included this requirement in their pro hac vice rules. ${ }^{36}$ As far as I can discover, none of the US jurisdictions that have included

31 See eg ABA Commission on Ethics 20/20, Resolution \& Report: Model Rule 5.5 (Unauthorized Practice of Law; Multijurisdictional Practice of Law) (November 2012), 5 ('Moreover, the members must be subject to effective regulation and discipline by a duly constituted professional body or public authority. This is the definition that has long been used in the ABA Model Rule on Licensing and Practice by Foreign Legal Consultants, which state supreme courts have adopted with no adverse consequences [citing the Georgia, Massachusetts, New Mexico, North Dakota, Utah, and Virginia foreign legal consultant rules']), www.americanbar.org/content/dam/ aba/administrative/ethics_2020/20121211_ethics_20_20_model_rule_5_5_foreign_in_house_resolution_ report_final.authcheckdam.pdf [hereinafter Original Report 107A re the Foreign In-House Counsel Rule]; ABA Commission on Ethics 20/20, Resolution \& Report: ABA Model Rule for Registration of In-House Counsel, 4 (used the same language as that quoted above in the Resolution and Report for Model Rule 5.5), www. americanbar.org/content/dam/aba/administrative/ethics_2020/20121211_ethics_20_20_registration_in_ house_foreign_lawyers_resolution_report_final.authcheckdam.pdf [hereinafter Original Report 107B re the Foreign In-House Counsel Registration Rule]; ABA Commission on Ethics 20/20, Resolution \& Report: ABA Model Rule on Pro Hac Vice Admission (November 2012), 5, www.americanbar.org/content/dam/aba/ administrative/ethics_2020/20121211_ethics_20_20_Pro_hac_vice_foreign_lawyers_resolution_report_final. authcheckdam.pdf [hereinafter Original Report $107 \mathrm{C}$ re the Foreign Pro Hac Vice Rule] ('In particular, the foreign lawyer must be a member in good standing of a recognized legal profession in the lawyer's home country, and the members of that profession must be subject to effective regulation and discipline by a duly constituted professional body or public authority. This longstanding ABA definition of a "foreign lawyer" has been adopted by the courts, and the Commission is not aware of any problems that have arisen from its use'). The report accompanying the 2006 amendments to the ABA Model FLC rule did not mention the 'effective regulation and discipline' requirement. See American Bar Association Section of Legal Education and Admissions to the Bar, Report to the House of Delegates, Report 301 A (adopted August 2006).

32 Thirteen of the 32 US jurisdictions that have FLC rules have included the 'effective regulation and discipline' language in their FLC rules. These jurisdictions are: 1) Delaware, 2) Georgia, 3) Idaho, 4) Indiana, 5) Iowa, 6) Massachusetts, 7) New Hampshire, 8) New York, 9) North Dakota, 10 Pennsylvania, 11) South Carolina, 12) Utah and 13) Virginia. New Mexico has deleted the word 'effective'; Louisiana requires that one is from a 'recognized legal profession' and Florida requires a professional disciplinary system that is 'generally consistent' with that in Florida. The remainder of US jurisdictions with an FLC rule do not include this requirement. See above, $\mathrm{n} 16$ for links to these FLC rules.

33 Ibid.

34 Of the seven states that have explicit foreign lawyer temporary practice rules, only Florida, Georgia and New Hampshire have incorporated the 'effective regulation and discipline' requirement into their rules. Delaware, North Carolina, Pennsylvania and Virginia have not. See above, $\mathbf{n} 18$.

35 Indiana, Georgia and Virginia include the 'effective regulation and discipline' requirement in their rules allowing foreign in-house counsel; Arizona, Connecticut, Delaware, Washington and Wisconsin do not. See rules in Original 107C Report (n 31) and above, n 19. All these state rules are available as links from www.americanbar. org/content/dam/aba/administrative/professional_responsibility/in_house_rules.authcheckdam.pdf.

36 See the foreign pro hac rules cited above, $\mathrm{n} 19$. 
an 'effective regulation and discipline' requirement have made public their interpretation, if any, of what is meant by the requirement that foreign lawyers be subject to 'effective regulation and discipline' in the foreign lawyer's home jurisdiction. ${ }^{37}$

\section{POSSIBLE EXPLANATIONS FOR THE LACK OF DISCUSSION}

As noted above, neither the ABA foreign lawyer mobility recommendations nor the accompanying reports explain the meaning of the requirement that a mobile foreign lawyer be subject to 'effective regulation and discipline'. US jurisdictions that have included this requirement have not publicly defined it. To my knowledge, there has never been an in-depth discussion by academics or others of the meaning of this phrase when used in US foreign lawyer mobility provisions.

Given the prevalence of the 'effective regulation and discipline' requirement and the fact that this requirement was reaffirmed as recently as 2013, I found myself asking why this requirement has not been defined or discussed in a meaningful fashion. Are there valid reasons why this type of discussion has not yet occurred and do these reasons require continued silence? I concluded that there might be several reasons why the 'effective regulation and discipline' issue has not yet been discussed, but none of these reasons require continued silence on this issue.

One explanation for the lack of discussion is the fact that global lawyer mobility is a relatively new phenomenon and that the regulatory system and commentary lag behind this reality. At the conferences I attend, one often hears the comment that the reality of globalisation is far ahead of the legal profession's regulatory structure. For example, many jurisdictions have not addressed the issue of 'choice of law' or double deontology for globally mobile lawyers even though this is an issue on which at least some global lawyers would like guidance. ${ }^{38}$ There are simply many more issues in this field than there are commentators. This factor, however, would not justify continued silence on this issue.

A second factor that might have contributed to the lack of discussion about the requirement that the foreign lawyer's home jurisdiction has a system of 'effective regulation and discipline' is the fact that the individuals who were most likely to notice the omission of guidance on this issue may have put this issue low on their priority list of issues to discuss given the lack of sufficient time to address all issues and given the possibility that a discussion of this issue might derail efforts to achieve greater foreign lawyer mobility. For example, I was a member of the 'Inbound Foreign Lawyers' Working Group of the ABA Commission

37 See eg email from Erica Moeser, President and Chief Executive Officer, National Conference of Bar Examiners, to Bar Exam Mailing List [on behalf of the author] (28 October 2013). It should be noted that this emailed request for information was sent with a very short deadline for responses and thus may not be completely reliable. None of the jurisdictions that responded to the author, however, indicated that their jurisdiction had adopted a substantive definition of the 'effective regulation and discipline' requirement, although a number expressed support for having the 'effective regulation and discipline' requirement included in the rule.

38 See eg ABA Commission on Ethics 20/20, Issues Paper Choice of Law in Cross Border Practice (released 18 January 2011), www.americanbar.org/content/dam/aba/migrated/2011_build/professional_responsibility/20111801. authcheckdam.pdf. 
on Ethics 20/20. ${ }^{39}$ In one of our initial meetings, during the discussion of what ultimately became the Commission's foreign in-house counsel proposal and the foreign pro hac vice proposal, I pointed out that the ABA had never offered any guidance on the meaning of the 'effective discipline' requirement. Some Working Group members responded by suggesting that because the requirement had been used for more than two decades in the FLC rule, there was no need for us to define the requirement. Because there seemed to be little or no interest in exploring the meaning of this requirement within the Working Group, I dropped the issue. One reason why I may not have pursued this issue within the Working Group was that I was reluctant to raise concerns that could provide an additional reason (or excuse) for regulators to ignore the ABA's foreign lawyer mobility recommendations. Although this type of reaction might be understandable, I do not believe that it justifies continued silence. $^{40}$

Third, some commentators may not have discussed the 'effective regulation and discipline' requirement because they may have concluded that the requirement will be impossible to define. In other areas of lawyer regulation, for example, there are commentators who have concluded that it is fruitless to attempt to come up with a principled definition. ${ }^{41}$ There are a number of scholars, for example, who believe that it is virtually impossible to define in a meaningful and principled way the type of transactional work that should be labelled as the unauthorised practice of law (and subject to criminal penalties) when performed by a nonlawyer. ${ }^{42}$

Although I am sympathetic to the argument that there may be some topics that are impossible to define, I am not ready to throw in the towel with respect to the issue of 'effective regulation and discipline?. If one decides that this is a requirement worth having (which is the topic addressed in the next section of this article), then I think it might be possible to put 'meat on the bones' and come up with proposed content for the 'effective regulation and discipline' requirement. In contrast to the issue of unauthorized practice of law or UPL, there has been very little thought paid to the issue of what it means to have a system of 'effective regulation and discipline'. Since knowledge can be built through small incremental steps, I believe that one should not conclude that it will prove impossible to define what is meant by 'effective regulation and discipline' without trying. The fact that there

39 SeeABACommission on Ethics 20/20, Introduction and Overview [to the House of Delegates Filings] (August 2012), www.americanbar.org/content/dam/aba/administrative/ethics_2020/20120508_ethics_20_20_final_hod_ introdution and overview_report.authcheckdam.pdf, 3 .

40 Despite my reluctance in the context of the ABA Working Group to pursue this issue, there were two reasons why I concluded that it was important to write this article. First, academics have an obligation to honestly identify issues and data. Secondly, and equally importantly, the failure to enforce existing laws (or model policies) can breed disrespect for the law and thus could prove injurious to the rule of law within a society. Thus, in my view, if US regulators are not willing to enforce the 'effective regulation and discipline' requirement, this requirement should be eliminated.

41 The ABA, for example, was unable to agree upon a model definition of the practice of law, and simply urged states to come up with a definition themselves. Some commentators have suggested that it may be impossible to come up with a meaningful definition of the practice of law that applies to transactional settings. See generally Laurel S Terry, 'Putting the Legal Profession's Monopoly on the Practice of Law in a Global Context' (2014) 82 Fordham Law Review (forthcoming).

42 See Terry, ibid. 
currently is no common understanding about the meaning of this term does not mean that such an understanding is impossible. It may prove difficult to agree upon the meaning of this requirement and the initial definitions may leave some dissatisfied, ${ }^{43}$ but progress is often made in incremental steps such as this. Thus, I would not advocate abandoning this project before one begins.

In sum, although there has, to date, been very little discussion of the 'effective regulation and discipline' requirement in foreign lawyer mobility provisions, this lack of discussion is attributable to multiple factors, none of which justify continued silence on this issue. Accordingly, I recommend that all US jurisdictions - including those that have foreign lawyer mobility provisions and those that have not yet adopted such provisions-consider the issues posed in the remainder of this article.

\section{GOING FORWARD: THRESHOLD QUESTIONS ONE MIGHT ASK REGARDING THE 'EFFECTIVE REGULATION AND DISCIPLINE' REQUIREMENT}

Assuming that one agrees that it is appropriate to acknowledge the elephant in the room and begin a discussion about the 'effective regulation and discipline' requirement, there are two 'threshold issues' that I believe one should consider before turning to the substantive content of this requirement. The first is whether the requirement should be omitted (or abandoned) because the premise that underlies it is flawed. Although many US jurisdictions (and Canada) ${ }^{44}$ do not include this type of requirement in their foreign lawyer mobility rules, ${ }^{45}$ as far as I can tell, the US lawyer regulatory community has never had a serious conversation about this issue.

43 Cf ABA Model Rule of Professional Conduct 8.5. The comment was amended in 2002 to make it clear that the rule applied to US lawyers with transnational practices. I consider this an incremental step forward from the previous status quo. In October 2010, however, the author and Professor Catherine Rogers submitted a suggestion to the ABA Commission on Ethics 20/20 suggesting further revisions to Rule 8.5 with respect to transnational legal practice. In my view, these suggestions, if they had been adopted, would have further improved the rule. See ABA 20/20 Choice of Law Paper (n 38) 6-7.

44 Canada, like the US, has foreign lawyer mobility rules but it does not seem to include in its rules an 'effective regulation and discipline' requirement. For full admission purposes, Canada examines the equivalence of the legal education provided in Canada and the foreign [Home] jurisdiction. Canada also asks a mobile foreign lawyer to identify the jurisdiction from which he or she comes and whether he or she is in good standing. It does not appear, however, that Canada makes any attempt to evaluate whether the foreign jurisdiction has a system of 'effective regulation and discipline'. See generally Federation of Law Societies of Canada, Canada's Law Societies, www.flsc.ca/en/canadas-law-societies (includes links to law society webpages with information for foreign lawyers); Law Society of Upper Canada, Lawyers from Outside Ontario, www.lsuc.on.ca/ For-Lawyers/About-Your-Licence/Lawyers-from-Outside-Ontario/Lawyers-from-Outside-Ontario (includes links to information about FLC licenses, temporary practice and full admission); See Law Society of Upper Canada, Application for Permit as a Foreign Legal Consultant (Under By-Law 14), www.lsuc.on.ca/WorkArea/ DownloadAsset.aspx?id=2147490494. I have had several informal conversations with Canadian regulators that have reinforced my conclusion that Canadian provinces do not appear to have adopted 'effective regulation' provisions comparable to those found in the ABA foreign lawyer mobility provisions or in some US states.

45 See above, nn 32-36. 
There are legitimate reasons why a jurisdiction —upon deliberation-might decide to omit this requirement from its foreign lawyer mobility rules. ${ }^{46}$ For example, a jurisdiction might conclude that it does not have the resources or expertise to evaluate whether a foreign jurisdiction's lawyer regulation and discipline system is 'effective'. Accordingly, it might decide that it is better to omit this requirement, rather than having a requirement on its books that it has no intention of enforcing. The countervailing argument is that a US jurisdiction might decide that it wants to retain this requirement because of the insurance' it provides the jurisdiction. ${ }^{47}$ The jurisdiction might also hope that at some time in the future, someone will provide a definition of 'effective regulation and discipline' that it might be able to use.

In considering whether to adopt or retain the 'effective regulation and discipline' requirement, a jurisdiction might also ask whether it is fair and appropriate to require as a condition of lawyer mobility that a foreign lawyer come from this type of legal system. A jurisdiction might conclude that there could be excellent worthy lawyers who come from regulatory systems that the US jurisdiction might consider inadequate and that it is unfair to penalise such lawyers for systemic faults for which they are not responsible and over which they have no control. A countervailing argument might be that fairness to foreign lawyers is not among the US jurisdiction's regulatory objectives. ${ }^{48}$

A jurisdiction considering whether to retain or adopt this requirement might also ask whether an 'effective regulation and discipline' requirement is fair to its own citizens who may be trying to expand their for-profit or non-profit business or services into other parts of the world and who may want access in the US to the services of a lawyer from the country in question. This question is similar to the second question in that it asks whether a foreign lawyer or that lawyer's clients should have to bear the burden of systemic flaws in the foreign lawyer's home jurisdiction, rather than personal flaws of the foreign lawyer. This point might be stronger than the second point, however, because a jurisdiction may include in its regulatory objectives access to justice and legal services for its own citizens. ${ }^{49}$ A countervailing argument might focus on the 'client protection' regulatory objective and argue that the risk to clients is too great if US jurisdictions grant mobility to foreign lawyers who come from systems that do not have effective regulation or discipline. ${ }^{50}$

Finally, a jurisdiction might ask whether, in the long run, abandoning this requirement might lead to greater global accountability and improvement in lawyer regulatory and discipline systems. ${ }^{51}$ This is similar to the types of debates that can arise in the human

46 Although a number of US jurisdictions omit the 'effective regulation and discipline' requirement, I have not seen anything to suggest that these actions were taken after discussion or debate.

47 This type of requirement, for example, would allow a US jurisdiction to reject a foreign lawyer if it thought that the foreign lawyer came from a rampantly corrupt system in which the law licence could be purchased and had little meaning. I do not know whether any such systems exist, but this requirement would provide 'insurance' in the event that they do.

48 See Laurel S Terry, Steve Mark and Tahlia Gordon, 'Adopting Regulatory Objectives for the Legal Profession' (2012) 80 Fordham Law Review 2685 (recommending that each US jurisdiction adopt regulatory objectives for the legal profession and use those to measure and evaluate new proposals).

49 Ibid, 2748 (Recommended Objective \#5).

50 Ibid, 2744 (Recommended Objective \#1).

51 See below, nn 54-57 and accompanying text for an expanded discussion of this point. 
rights context, when countries must decide whether continued engagement or cutting off ties would prove more productive. A jurisdiction might conclude that engagement is the more productive course of action. The countervailing argument might be that the risk is too large and that because the foreign lawyer's home jurisdiction license is used as the proxy for quality and accountability, a US jurisdiction should insist that the foreign lawyer come from a country that has effective lawyer regulation and discipline.

This article offers no opinion as to the optimal answer to this first threshold question. In my view, there are strong arguments in favour of adopting an 'effective regulation and discipline' requirement and strong arguments in favour of omitting such a requirement. There are three points, however, on which I will offer recommendations.

First, I believe that each jurisdiction should adopt foreign lawyer mobility provisions. The failure to do so ignores the reality of the modern world and provides no basis for a system of accountability. Second, I recommend that each jurisdiction make a deliberate, considered choice, after discussion and debate, with respect to whether it wants to include (or retain) an 'effective regulation and discipline' requirement in its foreign lawyer mobility provisions. Third, I recommend that if a jurisdiction decides to include (or retain) an 'effective regulation and discipline' requirement in its foreign lawyer mobility provisions, then it should determine what that requirement means, publicise it, and enforce it.

Assuming that a jurisdiction decides that it wants to adopt or retain an 'effective regulation and discipline' requirement, a second threshold issue that the jurisdiction may confront is whether to interpret this requirement so as to require regulation and discipline that is 'substantially equivalent' to that found in its own jurisdiction or that is 'generally consistent' with the jurisdiction's own system. ${ }^{52}$

There are several different reasons why I would not interpret the 'effective regulation and discipline' requirement in a way that requires 'substantial equivalence' or 'general consistency'. First, this interpretation seems inconsistent with the ABA drafters' intentions, given the distinction that was drawn in the report accompanying the 1993 ABA Model FLC Rule between the proposed ABA Model Rule and the Florida FLC rule. ${ }^{53}$ Second, even if the requirement is interpreted to require 'substantial equivalence', there is a risk that this recognition requirement will be interpreted to require a system that is 'substantially identical' to the US jurisdiction and will fail to recognise the validity of systems that look dramatically different but achieve the same goals.

Third, and in my view most importantly, there are valid policy reasons why a jurisdiction might want to grant mobility to foreign lawyers who come from regulatory systems that are not substantially equivalent to those found in the US. Global lawyer mobility is a fact of life and is not likely to change. ${ }^{54}$ To date, there have been nascent efforts to develop

52 Florida's rule requires a system that is 'generally consistent'. See above, $\mathrm{n} 32$.

53 See above, $\mathbf{n} 23$ and accompanying text for a discussion of footnote 33 in the 1993 ABA Report.

54 Given the data that shows that clients are moving around the global for both personal and business reasons, it seems inevitable that lawyers will continue to follow their clients around the globe. A 2010 World Trade Organization report included data and graphs that illustrated the global nature of trade in legal services. See 2010 WTO Report (n 5). US data shows a similar picture. See Recent Trends in US Services Trade: 2013 Anmual Report, Inv No 332-45, USITC Pub 4412 (July 2013) (Final), at 5-1, www.usitc.gov/publications/332/pub4412. pdf; Recent Trends in US Services Trade: 2011 Annual Report, Inv No 332-45, USITC Pub 4243 (July 2011) (Final), at 7-1, www.usitc.gov/publications/332/pub4243.pdf. See also Terry (n 4). 
global accountability systems to accompany this mobility, but these systems are still in their infancy and much more work needs to be done. ${ }^{55}$ The advantage of not requiring 'substantial equivalence' among regulatory systems is that this approach allows lawyers (and regulators) from less developed systems to interact and discuss regulatory issues with jurisdictions that have more developed regulatory systems. If one believes, as I do, that the US has one of the most effective lawyer regulatory systems in the world, then there are valid reasons why one might want to encourage mobility from lawyers whose regulatory systems are not as robust. ${ }^{56}$ Moreover, even if US systems are particularly strong and effective in some respects, there might be things they could learn with respect to other issues. Thus, even if one believes that the lawyer disciplinary system in another country has serious flaws, I submit that it is much better to encourage exchanges in which lawyers (and regulators) from one country can see how things are done in a different country and adopt ideas that seem useful. ${ }^{57}$ For this reason, for those US jurisdictions that adopt an 'effective regulation and discipline system requirement', I would not interpret this in a way that requires substantial equivalence between the US and the foreign system with respect to the foreign lawyer's home jurisdiction. I would instead try to establish the minimal requirements that one believes are necessary to ensure that recognition is appropriate.

This section has discussed two 'threshold issues' that US jurisdictions should consider before adopting or deciding to retain the 'effective regulation and discipline' requirement in their foreign lawyer mobility provisions. While reasonable minds may differ as to the optimal answers to these two threshold questions, it is important to begin asking these questions. In short, the time has come for all stakeholders, including regulators and commentators, to acknowledge the elephant in the room and to begin a serious discussion about the meaning of the 'effective regulation and discipline' requirement in US foreign lawyer mobility provisions. This requirement should either be defined and enforced or the requirement should be abandoned. To do otherwise breeds disrespect for the rule of law.

55 See eg Laurel S Terry, Carole Silver, Ellyn Rosen, Carol A Needham, Jennifer Haworth McCandless, Robert E Lutz and Peter D Ehrenhaft, 'Transnational Legal Practice: 2008 Year-in-Review' (2009) 43 International Lawyer 943, 956-7 (discussing the Conference of Chief Justices' resolutions with the Law Council of Australia and with the CCBE); American Bar Association, Resolution 104 [on International Information Exchange and Cooperation] (adopted 12-13 August 2013), www.americanbar.org/content/dam/aba/directories/ policy/2013 hod annual meeting 104.docx.

56 The US lawyer discipline system has not always been as robust as it currently is. The influential 1970 Clark Report, for example, noted many weaknesses in US lawyer discipline systems and led to many changes. See American Bar Association, Problems and Recommendations in Disciplinary Enforcement (1970) [hereinafter Clark Report], www.americanbar.org/content/dam/aba/migrated/cpr/reports/Clark Report.authcheckdam. pdf. There have been several additional studies since the Clark Report that have led to additional improvements in the US lawyer regulatory and discipline systems. Benchmarking data is easily available. See ABA Standing Committee on Professional Discipline, www.americanbar.org/groups/professional_responsibility/ committees_commissions/disciplinecommittee.html. The ABA has a Standing Committee on Professional Discipline that travels to states to evaluate their lawyer disciplinary system and offer suggestions. Ibid. There have been several other reports since the Clark Report that have recommended additional improvements. Ibid (listed under 'Related Resources').

57 See generally Laurel S Terry, 'Preserving the Rule of Law in the 21st Century: The Importance of Infrastructure and the Need to Create a Global Lawyer Regulatory Umbrella Organization' [2012] Michigan State Law Review $735,743-5$ (noting that in other fields in which regulators from different countries share information, there has been some convergence of policies as countries consider the best practices used elsewhere). 


\section{BENCHMARKING SOURCES THAT MIGHT HELP DEFINE THE 'EFFECTIVE REGULATION AND DISCIPLINE' REQUIREMENT}

In prior articles, I have argued that cross-profession and cross-cultural benchmarking can be useful when considering lawyer regulation issues. ${ }^{58}$ However, there is no scope in this article to conduct this type of 'mapping' or benchmarking. What this article can do, however, is point to 'benchmarking' sources that could be consulted at a later time with respect to this issue.

Before identifying sources that might provide useful benchmarking, however, it is worth noting that lawyer regulation covers three distinct time periods:

- entry into the profession or the beginning stage of regulation;

- conduct regulation or the middle stage of regulation; and

- discipline or the end stage of lawyer regulation. ${ }^{59}$

I have assumed in this article that when the ABA Model Rules require foreign lawyers to be subject to 'effective regulation and discipline', the word 'regulation' refers to the beginning and middle stages of lawyer regulation and the word 'discipline' refers to the third stage of lawyer regulation. The remainder of this article uses this structure and sets forth potential benchmarking tools that address the beginning and middle stages of lawyer regulation on the one hand, and the final stage of lawyer regulation (discipline) on the other.

\section{A. Sources that Might Shed Light on What Constitutes Effective Regulation}

There have been a number of international policies that have addressed-in one way or another-the topic of lawyer regulation and that might shed light on the optimal meaning of the phrase 'effective regulation'. Some of these are listed below: ${ }^{60}$

58 See eg Laurel Terry, 'The Future Regulation of the Legal Profession: The Impact of Treating the Legal Profession as "Service Providers"' [2008] Journal of the Professional Lawyer 189, 209-10; Terry (n 41). Some may argue that the US has the 'gold standard' in lawyer regulation and that there is no need to look at systems outside the US or any value in doing so. I disagree. In a complex world, we all benefit by regularly conducting crosscultural and cross-professional comparisons.

59 I have found it helpful to distinguish among these three time periods and three stages of regulation when trying to analyse lawyer regulatory systems in other countries. See generally Laurel S Terry, 'Creating an International Network of Lawyer Regulators: The 2012 International Conference of Legal Regulators' (2013) 82(2) Bar Examiner 18, http://papers.ssrn.com/sol3/papers.cfm?abstract_id=2283429 (using these time periods); Laurel $\mathrm{S}$ Terry, Lawyers, Regulation Of, in James Wright (ed), International Encyclopedia of the Sacial and Behavioral Sciences (Elsevier, 2nd edn forthcoming 2015).

60 In addition to these policies, there are a number of more specialised international or multilateral legal profession policies that might be illuminating with respect to global views on effective regulation of the legal profession. See eg the Hague Principles on Ethical Standards for Counsel Appearing before International Courts and Tribunals (September 2010), www.ila-hq.org/download.cfm/docid/90B50C7123D6-4366-B5E488C89D96559A; International Criminal Court, Code of Professional Conduct for Counsel (December 2005), www.icc-cpi.int/NR/rdonlyres/BD397ECF-8CA8-44EF-92C6-AB4BEBD55BE2/140121/ ICCASP432Res1_English.pdf; IBA Guidelines on Conflicts of Interest in International Arbitration (May 2004), www.int-bar.org/images/downloads/guidelines text.pdf. 
- 1990 UN Basic Principles on the Role of Lawyers; ${ }^{61}$

- 1998 IBA Core Values Resolution; ${ }^{62}$

- 2000 Council of Europe Recommendation on the Freedom of Exercise of the Profession of Lawyer; ${ }^{63}$

- 2002 Union Internationale des Avocats' Turin Principles of Professional Conduct for the Legal Profession; ${ }^{64}$

- 2005 Statement of Core Principles of the Legal Profession (which was endorsed by more than 100 bar presidents, including an ABA president $) ;{ }^{65}$

- 2006 IBA Statement of General Principles of the Legal Profession and International Principles on Conduct for the Legal Profession $(2011) ;{ }^{66}$

- 2006 European Parliament resolution on the legal profession; ${ }^{67}$ and

- 2007 Charter of core principles of the European legal profession and code of conduct for European Lawyers ${ }^{68}$

If I were charged with developing the meaning of the term 'effective regulation', I would want to consult these international policies.

In addition to the international policies, one might find it useful to conduct research regarding the 'effective regulation' requirements found in other countries. For example, Australian jurisdictions appear to have a requirement similar to that found in some US foreign lawyer mobility provisions. In 2008, a Law Council of Australia report summarised these requirements by noting that if a foreign lawyer wishes to become a foreign legal consultant (FLC) in Australia, the foreign lawyer must come from a home jurisdiction that

61 See Eighth UN Congress on the Prevention of Crime and the Treatment of Offenders, 27 August-7 September 1990, Basic Principles on the Role of Lawyers, UN Doc A/CONF.144/28/Rev.1 (1990) [hereinafter UN Basic Principles], wwwl.umn.edu/humanrts/instree/i3bprl.htm.

62 International Bar Association Resolution on the Regulation of the Legal Profession, www.ibanet.org/ Document/Default.aspx?DocumentUid=4094F728-9035-4C6C-8AB6-DE645546D26C.

63 Committee of Ministers, 25 October 2000, On the Freedom of Exercise of the Profession of Lawyer, Council of Europe Rec No R(2000)21.

64 Union Internationale des Avocats, Turin Principles of Professional Conduct for the Legal Profession in the 21st Century (October 2002), www.abanet.org/cpr/gats/uia_ex_1.pdf.

65 Statement of Core Principles of the Legal Profession (November 2005, endorsed by the ABA February 2006), http://apps.americanbar.org/intlaw/policy/ruleoflaw/coreprinciples.pdf; International Bar Association, IBA International Principles on Conduct for the Legal Profession (Adopted May 2011), www.ibanet.org/Docu ment/Default.aspx?DocumentUid=1730FC33-6D70-4469-9B9D-8A12C319468C. The 2011 Principles are substantially similar to the 2006 Principles, but now include commentary.

66 International Bar Association, IBA International Principles on Conduct for the Legal Profession (Adopted May 2011), www.ibanet.org/Document/Default.aspx?DocumentUid=1730FC33-6D70-4469-9B9D-8A12C31 9468C. The 2011 Principles are substantially similar to the 2006 Principles, but now include commentary.

67 European Parliament resolution on the legal professions and the general interest in the functioning of legal systems (23 March 2006), P6_TA(2006)0108, www.europarl.europa.eu/sides/getDoc.do?pubRef=-//EP// TEXT+TA+P6-TA-2006-0108+0+DOC+XML+V0//EN.

68 See eg Charter of core principles of the European legal profession and Code of Conduct for European lawyers [2008-11-29], www.ccbe.eu/fileadmin/user_upload/NTCdocument/EN_CCBE_CoCpdf1_1382973057.pdf. 
has 'an effective system of regulating the practice of law'. ${ }^{69}$ The $2008 \mathrm{Law}$ Council report does not provide any additional detail concerning the meaning of this phrase, but it summarises the requirement found in Australia's Model Legal Practice Bill, the provisions of which have been adopted in most Australian states and territories. ${ }^{70}$ For example, section 205 of the New South Wales Legal Profession Act states that the domestic registration authority must grant an application for registration as a foreign lawyer if, among other things, the authority 'considers an effective system exists for regulating engaging in legal practice in one or more of the foreign countries' ${ }^{71}$ Accordingly, those who are trying to determine the best way to interpret an 'effective regulation' requirement in the US might find it useful to find out more about how Australia has interpreted this requirement, if at all, in its foreign legal consultant rules. ${ }^{72}$

US regulators and commentators might also find it useful to examine the situation in England and Wales when trying to determine the meaning of the 'effective regulation and discipline' provision in US foreign lawyer mobility provisions. There are at least two different contexts in which this issue arises in England and Wales. ${ }^{73}$ In one of these two situations, the Solicitors Regulation Authority (SRA) has-in essence-defined what it means to have effective regulation; in the other situation, the SRA has not yet done so publicly, but it has signalled its intention to do so in the future.

69 See Law Council of Australia, Foreign Lawyers and the Practise of Foreign Law in Australia: An Information Paper (2008), wwwl.lawcouncil.asn.au/lawcouncil/images/LCA-PDF/Foreign-Lawyers-and-the-practise-offoreign-law.pdf, 7 .

70 See eg Australia Legal Profession-Model Laws Project, Model Bill (Model Provisions), 2nd edn (August 2006), wwwl.lawcouncil.asn.au/lawcouncil/images/LCA-PDF/a-2-docs/NPP01 107ModelBill2ndEditionAugust2006updated6Feb07 (pcc-legal-prof-2006-d21).pdf at s 2.8.23(1)(b) (The domestic registration authority must grant an application for registration as a foreign lawyer if the domestic registration authority: ... (b) considers an effective system exists for regulating engaging in legal practice in one or more of the foreign countries'); Legal Profession Act 2004, Victoria, s 2.8.22(1)(b) (“(1) The Board must grant an application for registration as a foreign lawyer ... (b) if the Board-considers an effective system exists for regulating engaging in legal practice in one or more of the foreign countries'), www.austlii.edu.au/au/legis/ vic/consol_act/lpa2004179/index.html\#s2.8.22. See also Law Council of Australia, The Model Legal Profession Bill: Status of Implementation, www.lawcouncil.asn.au/lawcouncil/index.php/divisions/national-professionproject/the-model-legal-profession-bill ('Between 2004 and 2008 the States and territories (apart from South Australia) enacted a Legal Profession Act based on the template of the model legislation').

71 New South Wales, Legal Profession Act 2004, part 2.7-Legal Practice by Foreign Lawyers, www.austlii.edu.au/ au/legis/nsw/consol_act/lpa2004179/s205.html.

72 In contrast to the situation in the US, I could not find any 'effective regulatory system' requirement in Australian rules or policies regarding temporary practice by foreign lawyers or full admission of foreign lawyers. Cf New South Wales, Legal Profession Act 2004, Part 2.7 (n 71) s 205(1)(b) at 186 ('(1) A person must not practise foreign law in this jurisdiction unless the person is: (a) an Australian-registered foreign lawyer, or (b) an Australian legal practitioner. (2) However, a person does not contravene subsection (1) if the person is an overseas-registered foreign lawyer: (a) who (i) practises foreign law in this jurisdiction for one or more periods that do not in aggregate exceed 90 days in any period of 12 months ...'); Law Admissions Consultative Committee, Uniform Principles for Assessing Qualifications of Overseas Applicants for Admission to the Australian Legal Profession (June 2011), www.lpab.lawlink.nsw.gov.au/agdbasev7wr/lpab/documents/ pdf/uniform\%20principles.pdf, Schedule 2, pp 16-20, and Schedule 5: Common Considerations Relevant to Experienced Practitioners, p 49, at (f)(6).

73 Although there may be additional contexts in which regulators located in UK jurisdictions have to examine the regulatory systems from which foreign lawyers hail, this article limits itself to one regulator-the Solicitors Regulation Authority or SRA — which governs the regulation of solicitors in England and Wales. 
The first context in which the question of effective regulation arises is when a foreign lawyer wants to take advantage of the SRA's Qualified Lawyer Transfer Scheme (QLTS) and become a fully qualified solicitor. The SRA has established in the QLTS a series of requirements that differ depending on the foreign jurisdiction in which the foreign applicant lawyer is licensed. Not all lawyers from all countries are eligible to use the QLTS system: the SRA's webpage lists those jurisdictions from which QLTS applicants must come. ${ }^{74}$ Even more significantly, a foreign jurisdiction must apply to the SRA in order for its lawyers to be eligible to use the QLTS system. For example, some but not all US jurisdictions are 'recognised foreign jurisdictions' whose lawyers are entitled to use the QLTS system. ${ }^{75}$

In order to become a 'recognised jurisdiction', three requirements must be satisfied:

- the professional qualification requires completion of specific education and training at a level that is at least equivalent to that of an English or Welsh bachelor's degree;

- members of the profession are bound by an ethical code that requires them to act without conflicts of interest and to respect their clients' interests and confidentiality; and

- members of the profession are subject to disciplinary sanctions for breach of their ethical code, including the removal of the right to practise. ${ }^{76}$

In addition to satisfying these requirements, jurisdictions must submit an application to the SRA in order to be recognised. At the time that the US state of Georgia applied to be a 'recognised jurisdiction', the application form consisted of 15 questions. ${ }^{77}$

The second context in which the issue of adequacy of a foreign lawyer's home regulatory system arises is in the context of regulations that specify who may serve as a manager of a registered body. (Because the SRA now uses an entity-based system of lawyer regulation, all solicitors must be part of a 'recognised body' even if they practise as a solo practitioner.) The Courts and Legal Services Act 1990 sets forth the conditions under which foreign lawyers may serve as managers of recognised bodies. Section 2(2) of this Act provides that:

(2) Where such an application is duly made by a foreign lawyer, the Law Society may register the applicant if it is satisfied that the legal profession of which the applicant is a member is one

74 See Solicitors Regulation Authority (England and Wales), List of Recognised Jurisdictions and Qualified Lawyers, last updated 4 October 2013, www.sra.org.uk/solicitors/glts/recognised-jurisdictions.page.

75 See ibid. On the 2 April 2013 list, 35 US states were 'recognised' jurisdictions. In contrast, all of the Canadian provinces and territories and Australian states and territories were recognised jurisdictions.

76 See Solicitors Regulation Authority (England and Wales), Key Features of the New Transfer Scheme, last updated 20 February 2012, www.sra.org.uk/solicitors/glts/key-features.page\#recjur. This webpage summarises the QLTS requirements found in the SRA Handbook, which is the set of principles that govern English and Welsh solicitors. Between October 2011 when it was first issued and 15 October 2013, the SRA Handbook had gone through eight versions, but the QLTS system remained unchanged. See Solicitors Regulation Authority, SRA Handbook: History: QLTS Assessments, www.sra.org.uk/solicitors/handbook/glts/part3/rule3/history.page (showing no changes between versions 1 and 8 ).

77 See email from William Smith, Former General Counsel, State Bar of Georgia, to the author enclosing the partially completed application form (23 April 2013) (on file with author). 
which is so regulated as to make it appropriate for members of that profession to be managers of recognised bodies. ${ }^{78}$

In contrast to the QLTS situation, however, neither the SRA webpage nor the SRA Handbook specifies how the SRA will determine whether particular foreign lawyers are 'so regulated as to make it appropriate for members of those professions to be managers of recognised bodies. ${ }^{79}$ In contrast to the QLTS system, which only recognises lawyers from 35 US jurisdictions, this SRA webpage indicates that lawyers from all US jurisdictions may serve as managers of registered bodies. ${ }^{80}$ The SRA webpage states that the SRA will consider whether other professions should be added to this list as and when requested to do so. ${ }^{31}$ What is missing from the SRA webpage, however, is a statement of how the SRA goes about determining that a foreign lawyer 'is so regulated as to make it appropriate for members of that profession to be managers of recognised bodies'. Indeed, the SRA webpage states that it is currently reviewing its 'requirements governing registered foreign lawyer registration and will produce some proposals later in 2013, ${ }^{82}$ Both the QLTS rule and the 'recognised bodies' rules suggest that if and when US jurisdictions adopt an 'effective regulation and discipline' requirement, they may find it useful to speak to officials at the SRA.

As this brief discussion illustrates, when regulators and commentators consider the meaning of US policies and rules that require 'effective regulation and discipline', they may find it helpful to: (1) review the policies adopted by various international or regional organisations with respect to the topic of lawyer regulation; (2) speak with Australian regulators and other stakeholders regarding implementation of Australia's 'effective regulation' requirement; and (3) learn more about the QLTS standards found in the SRA Handbook and the SRA's work on the issue of which professions are suitable to be managers of 'recognised bodies'

\section{B. Sources that Might Shed Light on What Constitutes Effective Discipline}

As noted earlier, the $\mathrm{ABA}$ foreign lawyer mobility provisions require a mobile foreign lawyer to be subject to 'effective discipline' as well as 'effective regulation'. When trying to provide content to this requirement, one might—once again — find it useful to look at resources from outside the US, as well as US resources such as the ABA Model Rules of Disciplinary Enforcement. $^{83}$

78 UK, Courts and Legal Services Act 1990 [amended as of 1 July 2009], www.sra.org.uk/sra/regulatoryframework/Courts-and-Legal-Services-Act-1990.page (emphasis added).

79 See SRA, Professions Approved by the SRA for Registered Foreign Lawyer (RFL) Status, updated 12 July 2013, www.sra.org.uk/sra/regulatory-framework/professions-approved-by-SRA-for-RFL-status.page; SRA, SRA Handbook, www.sra.org.uk/handbook.

80 SRA, Professions Approved, ibid.

81 Ibid (emphasis added).

82 See SRA, Professions Approved by the SRA (n 79).

83 See ABA Standing Committee on Professional Discipline, Model Rules For Lawyer Disciplinary Enforcement (2007), www.abanet.org/cpr/disenf/contents.html. The ABA Center for Professional Responsibility provides links to a number of addition useful resources on the webpage of its Standing Committee on Professional Discipline:see www.americanbar.org/groups/professional_responsibility/committees_commissions/discipline committee.html. 
There are two different types of international resources that might provide guidance when providing content to the 'effective discipline' requirement. The first is exemplified by the UN's Basic Principles, which set forth what one might call 'meta' principles that should underlie a lawyer discipline system. ${ }^{84}$ One might also consult more detailed lawyer discipline policies that were developed on a multi-lateral, multi-cultural basis since those provisions presumably reflect a shared understanding of lawyer discipline such as those developed by the IBA or the Council of Bars and Law Societies of Europe, which is known as the $\mathrm{CCBE}^{85}$ These resources include the following:

- UN's Basic Principles on the Role of Lawyers; ${ }^{86}$

- Council of Europe: Recommendation on the Freedom of Exercise of the Professional Lawyer; ${ }^{87}$

- CCBE Recommendations on Disciplinary Process for the Legal Profession; ${ }^{88}$

- IBA Guide for Establishing and Maintaining Complaints and Discipline Procedures; ${ }^{89}$

- IBA's summary of the results of its survey of lawyer discipline systems; ${ }^{90}$ and

- discipline procedures used in the International Criminal Court and other international tribunals. ${ }^{91}$

In addition to these international policies, US regulators might, once again, find it useful to speak to their counterparts in other countries. For example, as noted earlier, in order for a foreign jurisdiction to become a 'recognised jurisdiction' in England and Wales for the

84 See UN Basic Principles (n 61).

85 See eg International Bar Association, Guide for Establishing and Maintaining Complaints and Discipline Procedures (October 2007), www.ibanet.org/Document/Default.aspx?DocumentUid=2A17AA40-79A9-4B9990A6-D0A7825FD76F [hereinafter International Bar Association Guide]; $n 88$ below.

86 See UN Basic Principles (n 61).

87 See Council of Europe Recommendation (n 63).

88 See Council of Bars and Law Societies of Europe, CCBE Recommendations on Disciplinary Process for the Legal Profession (17 September 2007), www.ccbe.eu/fileadmin/user_upload/NTCdocument/CCBE Recommendations1_1190034926.pdf [hereinafter CCBE Recommendations]; see also Press Release, 'Council of Bars and Law Societies of Europe, CCBE Adopts Basic Principles on Disciplinary Process for Lawyers' (24 September 2007), www.ccbe.eu/fileadmin/user_upload/NTCdocument/pr_0907_enpdf1_1190726675.pdf.

89 See International Bar Association Guide (n 85).

90 See International Bar Association, Summary of Complaint Survey (July 2006), www.ibanet.org/Document/ Default.aspx?DocumentUid $=8451$ baa4-0e50-453f-91f3-b92106ddf115. This webpage is available as a link from IBA Complaints Procedures, www.ibanet.org/barassociations/bar_associations_complaints_procedures. aspx. As this webpage indicates, the IBA has posted information online about the lawyer discipline systems in several countries.

91 The ICC's disciplinary measures for judges and prosecutors are located under section 4 of the Rules of Procedure and Evidence. The disciplinary process for 'defence counsel, counsel acting for States, amici curiae and counsel or legal representatives for victims and witnesses' is similar to that for ICC prosecutors and judges but is found in chapter 4 of the Code of Professional Conduct for counsel. See Schreck (n 2) 13. As Schreck notes, the International Criminal Tribunal for the Former Yugoslavia (ICTY) and the International Criminal Tribunal for Rwanda (ICTR) do not contain disciplinary proceedings sections. Instead, both the ICTY and ICTR use Rule 46, entitled Misconduct of Counsel, and Rule 77, entitled Contempt of the Tribunal, from the Tribunals' Rules of Procedure and Evidence as the 'disciplinary proceedings'. The combination of Rules 46 and 77 , however, does not constitute formal disciplinary proceedings as described by other international organisations. Ibid, 16-17. 
purposes of the QLTS, that jurisdiction must submit evidence that its members 'are subject to disciplinary sanctions for breach of their ethical code, including the removal of the right to practise. $^{92}$ While the SRA does not appear to have explicitly required that the discipline system be 'effective', US stakeholders may find it worthwhile to explore this issue further with SRA representatives. Other than this SRA requirement, however, I am not aware of any other countries that require mobile foreign lawyers to come from systems that have 'effective discipline.'93

\section{Resources from Other Professions and Disciplines}

As noted earlier, it is useful for lawyer regulators and other stakeholders to compare their own system of regulation to the systems used by other professions and in other countries. ${ }^{94}$ While cross-professional treatment of 'effective regulation and discipline' requirements is beyond the scope of my expertise, I am aware of a number of resources that might offer useful information. This section of the article identifies some of those resources; undoubtedly there are many others.

One might begin this type of research by examining regulatory theory scholarship, including but not limited to scholarship that focuses on the goals and justifications for lawyer regulation. ${ }^{95}$ Second, there are a number of intergovernmental organisations that have devoted significant resources to the topic of regulation; these entities might offer useful information that one could use when trying to provide content and meaning to the 'effective regulation and discipline' requirement. ${ }^{96} \mathrm{~A}$ third source of information might be the recognition' policies that a particular country uses for various kinds of professions. Fortunately, as a result of the Lisbon Convention, the Bologna Process and other initiatives, ${ }^{97}$ many

92 See above, $\mathbf{n} 75$.

93 This, however, may simply be indicative of my lack of knowledge, rather than the lack of such a requirement. The usefulness of these types of cross-cultural exchanges illustrates the potential value of an international network of legal regulators. See 'Creating an International Network' (n 59).

94 See $n 58$.

95 See eg Christopher Decker and George Yarrow, Understanding the Economic Rationale for Legal Services Regulation: A Report for the Legal Services Board (31 October 2010), www.legalservicesboard.org.uk/news_ publications/latest_news/pdf/economic_rationale_for_Legal_Services_Regulation_Final.pdf; Legal Services Board, Understanding the Economic Rationale for Legal Services Regulation: A Collection of Essays (March 2011), www.legalservicesboard.org.uk/news_publications/latest_news/pdf/economics_of_legal_services_regu lation discussion papers publication final.pdf; Benjamin H Barton, 'Why Do We Regulate Lawyers? An Economic Analysis of the Justifications for Entry and Conduct Regulation' (2001) 33 Arizona State Law Journal 429; Gillian K Hadfield, 'Legal Barriers to Innovation: The Growing Economic Cost of Professional Control over Corporate Legal Markets' (2008) 60 Stanford Law Review 1689.

96 See eg Organisation for Economic Co-operation and Development (OECD), Regulatory Reform (including the many documents linked from this webpage), www.oecd.org/regreform; OECD, Recommendations and Guidelines on Regulatory Policy, www.oecd.org/gov/regulatory-policy/recommendations-guidelines.htm; OECD, Regulatory Policy: Overview of Work and Projects, www.oecd.org/gov/regulatory-policy/themesprojects.htm; APEC-OECD, Integrated Checklist on Regulatory Reform, www.oecd.org/regreform/34989455. pdf.

97 See eg Laurel S Terry, 'International Initiatives that Facilitate Global Mobility in Higher Education' [2011] Michigan State Law Review 305, 347-50; Laurel S Terry, 'The Bologna Process and its Impact in Europe: Much More than Degree Changes' (2008) 41 Vanderbilt Journal of Transnational Law 107, 137. 
countries, including the US, have consolidated sources to which one can look for information about recognition of foreign qualifications. ${ }^{98}$ Thus, one might examine whether recognition policies for the medical, engineering, pharmacy and architecture fields, among others, require, as a condition of recognition, that the foreign professional has come from a foreign country that has an 'effective regulation and discipline' system. In sum, if one were serious about trying to provide meaning to the phrase 'effective regulation and discipline', there are a number of resources that one could usefully consult.

\section{CONCLUSION}

All of the ABA's foreign lawyer mobility recommendations state that a foreign lawyer must be subject to 'effective regulation and discipline' in the lawyer's home jurisdiction. A number of US jurisdictions have included this requirement in their own foreign lawyer mobility provisions. To date, however, this requirement has not been defined or, to my knowledge, enforced. If global lawyer mobility is going to be accompanied by a system of accountability, which many have recommended and which I endorse, then our society needs to have a serious discussion about whether this requirement is necessary as part of that accountability system. If the requirement is to be retained, then US jurisdictions should determine what the requirement means and how it should be enforced. In short, the thesis of this article is that the time has come for the US legal profession to explicitly acknowledge the elephant in the room, which is the 'effective regulation and discipline' requirement in US foreign lawyer mobility provisions. This requirement should either be defined and enforced, or abandoned. Let the discussions begin!

See eg US Department of Education, USNEI: Information for International Students and Professionals, www2. ed.gov/about/offices/list/ous/international/usnei/us/edlite-students.html. For links to the portals in a number of other countries, see ENIC-NARIC.net, Gateway to Recognition of Academic and Professional Qualifications, http://enic-naric.net/index.aspx?s $=\mathrm{n} \& \mathrm{r}=\mathrm{g} \& \mathrm{~d}=$ about. 